\title{
Antibacterial Activity of Red Dragon Fruit Leaves Extract and White Dragon Fruit Leaves Extract Against Meningitis Bacterial
}

\author{
KIKING RITARWAN ${ }^{1}$ and NERDY NERDY ${ }^{2 *}$ \\ 'Department of Neurology, Faculty of Medicine, Universitas Sumatera Utara, Medan Selayang, Medan \\ Baru, Sumatera Utara, 20155, Indonesia. \\ 2Department of Pharmaceutical Chemistry, Faculty of Pharmacy, Universitas Sumatera Utara, Medan \\ Selayang, Medan Baru, Sumatera Utara, 20155, Indonesia. \\ ${ }^{*}$ Correspondence author E-mail: nerdy190690@ gmail.com \\ http://dx.doi.org/10.13005/ojc/340540
}

(Received: August 29, 2018; Accepted: October 01, 2018)

\begin{abstract}
Dragon fruit leaves extract contains various phytochemicals, namely: alkaloids, flavonoids, tannins, saponins, glycosides, steroids, and terpenoids. Diverse phytochemical content allows the dragon fruit leaves extract to have antibacterial activity. The objectives of this research were to test antibacterial activity of dragon fruit leaves extract against meningitis bacterial (Neisseria meningitidis, Streptococcus pneumoniae, and Listeria monocytogenes). Dragon fruit leaves extract was obtained by maceration. Antibacterial activity test was done by the paper disc diffusion method with ceftriaxone as the positive control and dimethylsulfoxide as the negative control. Antibacterial activity of red dragon leaves extract with concentration $600 \mu \mathrm{g} / \mathrm{mL}$ and white dragon fruit leaves extract with concentration $800 \mu \mathrm{g} / \mathrm{mL}$ were not show significantly different antibacterial activity from ceftriaxone with concentration $10 \mu \mathrm{g} / \mathrm{mL}$ against meningitis bacterial (Neisseria meningitidis, Streptococcus pneumoniae, and Listeria monocytogenes). The results prove that the red dragon fruit leaves extract was more potential antibacterial activity than white dragon fruit leaves extracted against meningitis bacterial (Neisseria meningitidis, Streptococcus pneumoniae, and Listeria monocytogenes).
\end{abstract}

Keywords: Antibacterial Activity, Dragon Fruit, Neisseria meningitidis, Streptococcus neumoniae, Listeria monocytogenes

\section{INTRODUCTION}

Meningitis is inflamed in the meninges which function as a protector of the brain and spinal cord. Meningitis is caused by five main factors, namely bacterial, viruses, fungi, amoeba and several diseases. The main cause of meningitis is caused by bacteria. The bacteria that cause bacterial meningitis are Neisseria meningitidis, Streptococcus pneumoniae, Listeria monocytogenes, Haemophilus influenzae, and Escherichia coli. The most common cause of bacterial meningitis is Neisseria meningitidis. These bacteria can live in the nose and throat without causing infection. But, there is a time when these 
bacteria can fight and defeat the human immune system resulting in meningitis. In general, adults have immunity to Neisseria meningitidis. These bacteria cannot live long outside the human body. These bacteria are usually spread through direct contact or at close range, for example through coughing, sneezing, or kissing. Streptococcus pneumoniae can also live on the nose and throat of humans without causing infection. But when the human immune system goes down, this bacteria can attack and cause meningitis. These bacteria cause meningitis in infants more often, when their immune system is not fully developed ${ }^{1}$.

Dragon fruit leaves extract contains various phytochemicals, namely: alkaloids, flavonoids, tannins, saponins, glycosides, steroids, and terpenoids ${ }^{2}$. Several phytochemical has been tested for the antidiabetic ${ }^{3}$, antimalarial ${ }^{4,5}$, anticancer ${ }^{4,6-7}$, anticonvulsant8 and antinephrolitiatic ${ }^{9}$ activity. The antioxidant ${ }^{10,11}$, antidiabetic ${ }^{12,13}$, antihypercholesterolemic ${ }^{14}$, hepatoprotective ${ }^{15}$, and anticancer ${ }^{16}$, activity has been observed from dragon fruit flesh. The antibacterial ${ }^{17,18}$ and antioxidant ${ }^{10}$ activity has been observed from dragon fruit peel. But until now no research observed the antibacterial activity of dragon fruit leaves against meningitis bacterial (Neisseria meningitidis, Streptococcus pneumoniae, and Listeria monocytogenes). In this research the objectives was to observed antibacterial activity test of dragon fruit leaves against meningitis bacterial (Neisseria meningitidis, Streptococcus pneumoniae, and Listeria monocytogenes).

\section{MATERIALS AND METHODS}

\section{Tools and Materials}

The tools used in this research were micropipette (Eppendorf), autoclave (Fison), oven (Fischer), paper disc (Oxoid), vortex (Health), and other glassware (Iwaki).

The materials used in this research were Mc Farland Standard Suspension (Biosan), Nutrient Broth (Oxoid), Nutrient Agar (Oxoid), Neisseria meningitidis (Thermo), Streptococcus pneumoniae (Thermo), and Listeria monocytogenes (Thermo), and other chemical (E-Merck).

\section{Sample Collection}

Sampling is purposively done without comparing with the same sample from other places.
The sample used was white dragon fruit leaves (Hylocereus polyrhizus) and red dragon fruit leaves (Hylocereus undatus). Which was green colours obtained from the farmers in Gundaling, Sumatera Utara, Indonesia.

\section{Sample Identification}

Identification of white dragon fruit (Hylocereus polyrhizus) leaves and red dragon fruit (Hylocereus undatus) leaves was carried out at Herbarium Medanense, Laboratory of Herbarium, Faculty of Mathematics and Natural Sciences, University of Sumatra Utara, Medan Selayang, Medan Baru, Sumatera Utara, 20155, Indonesia.

\section{Preparation of Extract}

The extraction process was based on modification of Nazliniwaty et al., reserach, the part used is white dragon fruit (Hylocereus polyrhizus) leaves and red dragon fruit (Hylocereus undatus) leaves. The leaves are cleaned, washed with running water, drained, dried in a drying cabinet at a temperature of $\pm 40^{\circ} \mathrm{C}$ to dry, smoothed using a blender, then stored in a tightly closed glass container. $0.5 \mathrm{~kg}$ of dragon fruit leaves was soaked for 5 days with $5 \mathrm{~L}$ methanol, and filtered the mixture. Extract was evaporated with a rotary evaporator until a viscous extract was obtained ${ }^{19,20}$.

\section{Antibacterial Activity Test}

The antibacterial activity was based on modification of Karsono et al., reserach and Masfria et al., research, tools and materials that will be used in an antibacterial activity test must be free from the presence of microbes so they are sterilized before being used in experiments. The growth media was sterilized in autoclave at $121^{\circ} \mathrm{C}$ for $15 \mathrm{~min}$. and the glassware used was sterilized in an oven at $170^{\circ} \mathrm{C}$ for 1 hour. Inoculating loop and lux are sterilized by burning with bunsen flame. $10 \mathrm{~g}$ of red dragon fruit leaves extract and white dragon fruit leaves extract was weighed, inserted into a $10.0 \mathrm{~mL}$ volumetric flask, added $60.0 \mathrm{~mL}$ of dimethylsulfoxide, shaken until dissolved, diluted with dimethylsulfoxide to the marked line, and shaken homogeneously (obtained extract solutions with concentration $1000 \mathrm{mg} / \mathrm{mL}$ ). Solution was diluted with dimethylsulfoxide to obtain solutions with concentration $1000 \mu \mathrm{g} / \mathrm{mL} ; 800 \mu \mathrm{g} / \mathrm{mL}$; $600 \mu \mathrm{g} / \mathrm{mL} ; 400 \mu \mathrm{g} / \mathrm{mL} ; 200 \mu \mathrm{g} / \mathrm{mL} ; 100 \mu \mathrm{g} / \mathrm{mL}$. The bacterial colony was taken from the culture stock with a sterile inoculating loop, then suspended in a 
test tube containing $10 \mathrm{~mL}$ of nutrient broth solution, incubated until the same turbidity was obtained with the Mc Farland standard solution meaning that the bacterial concentration was $108 \mathrm{CFU} / \mathrm{mL}$. Dilution of bacterial suspension by pippeting $0.1 \mathrm{~mL}$ of bacterial inoculum was inserted into a test tube containing $9.9 \mathrm{~mL}$ of nutrient broth solution and incubated in an incubator until homogeneous, the bacterial suspension concentration was $106 \mathrm{CFU} / \mathrm{mL}$. A total of $0.1 \mathrm{~mL}$ of inoculum was placed in a sterile petri dish, then the agar medium was poured as much as $15 \mathrm{~mL}$ with a temperature of $50^{\circ} \mathrm{C}$. Petri dishes are rocked on the table surface so that the media and bacterial suspension are evenly mixed and left to solidify. Paper discs that have been soaked into the test solution at various concentrations are awaited until they are fully diffused, then placed on the surface of solid media that has been inoculated with bacteria, and incubated in an incubator at $37^{\circ} \mathrm{C}$ for $20 \mathrm{~h}$ then the diameter of the inhibitory area around the paper tray is measured by using vernier caliper. This test was carried out 3 times $^{21,22}$.

\section{RESULTS AND DISCUSSION}

Antibacterial activity test results showed that the red dragon fruit leaves extract and white dragon fruit leaves extract can inhibit the growth of bacteria against meningitis bacterial (Neisseria meningitidis, Streptococcus pneumoniae, and Listeria monocytogenes). The method used in this test is the diffusion method in order to use paper discs by measuring the diameter of the inhibitory zone of bacterial growth as indicated by the presence of clear zones in the agar medium of bacterial growth. The antibacterial activity test results of red dragon fruit leaves extract and white dragon fruit leaves extract to meningitis bacterial (Neisseria meningitidis, Streptococcus pneumoniae, and Listeria monocytogenes) can be seen in Table 1.

Dimethylsulfoxide as the negative control do not give inhibitory activity against meningitis bacterial (Neisseria meningitidis, Streptococcus pneumoniae, and Listeria monocytogenes) so that it is very suitable to be used as a carrier to dissolve the extract. Ceftriaxone as the positive control give inhibition activity against meningitis bacterial (Neisseria meningitidis, Streptococcus pneumoniae, and Listeria monocytogenes). Antibacterial activity of red dragon fruit extract with concentration 600 $\mu \mathrm{g} / \mathrm{mL}$ was not significantly different from ceftriaxone with concentration $10 \mu \mathrm{g} / \mathrm{mL}$. Antibacterial activity of white dragon fruit with concentration $800 \mu \mathrm{g} / \mathrm{mL}$ was not significant different from ceftriaxone with concentration $10 \mu \mathrm{g} / \mathrm{mL}$. These results indicate that the red dragon fruit leaves extract has more potential antibacterial activity than white dragon fruit leaves extracted against meningitis bacterial (Neisseria meningitidis, Streptococcus pneumoniae, and Listeria monocytogenes). This can occur because the phenolic compounds in the red dragon fruit leaves extract is more abundant than white dragon fruit leaves extract ${ }^{2}$.

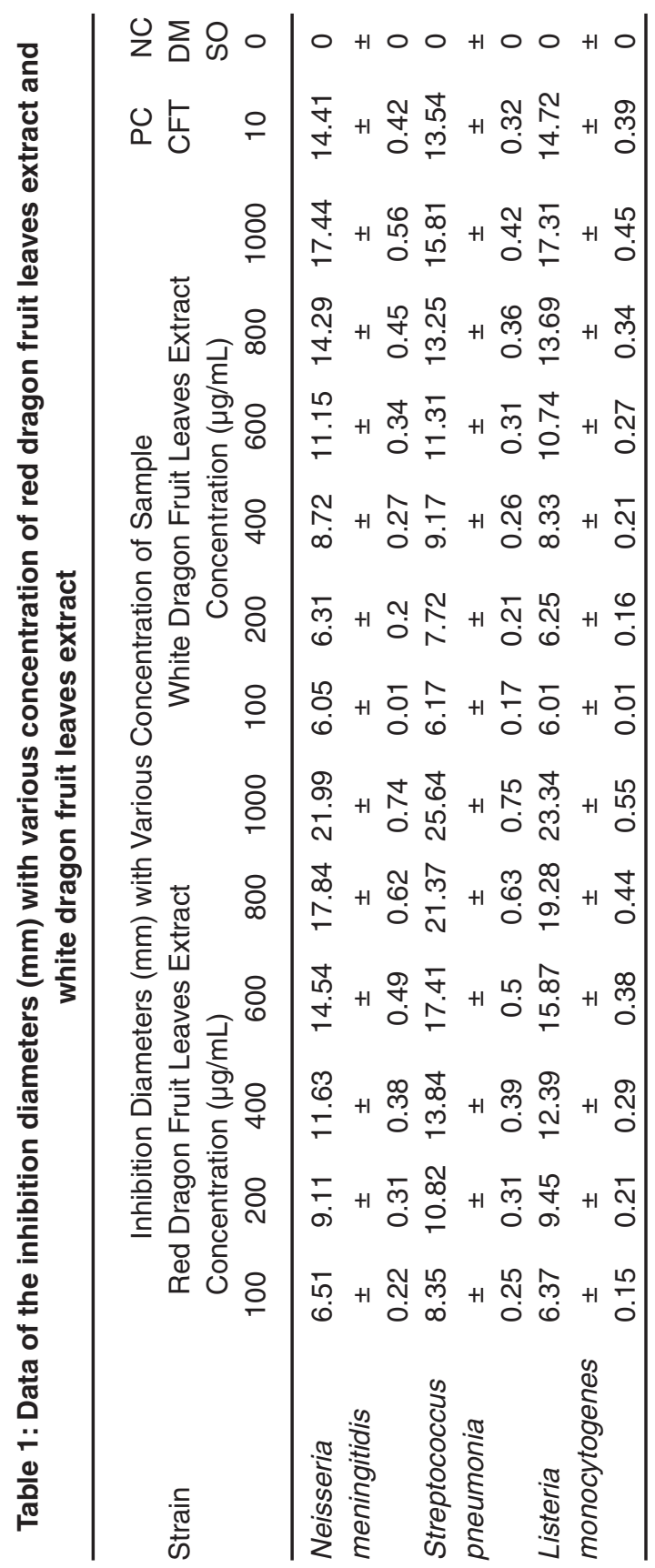


In the all of test concentration range obtained a smaller diameter of the inhibitory zone against Neisseria meningitidis than against Streptococcus pneumoniae and against Listeria monocytogenes. This difference occurs because the two test bacteria have different cell wall composition and structure resulting in Gram positive bacteria more susceptible to chemical compounds than Gram negative. The cell structure of Gram positive bacteria is simpler, that is single layered with a low lipid content making it easier for bioactive ingredients to enter the cell. Gram negative bacterial cell wall structure is more complex, namely three layers consisting of an outer layer of lipoprotein, a middle layer of lipopolysacrida which acts as a barrier to the entry of antibacterial bioactive material, and an inner layer of peptidoglycan in high lipid content ${ }^{23}$. The higher the concentration of red dragon fruit leaves extract and white dragon fruit leaves extract shows the higher the antibacterial activity. This result shows that the red dragon fruit leaves extract and white dragon fruit leaves have a dose dependent antibacterial activity. Flavonoids are known to have antimicrobial activity by forming complexes with bacterial cell walls. Flavonoids work by destroying bacterial cell membranes in the phospholipid portion, thereby reducing permeability because phenolic compounds result in changes in the composition of the phospholipid membrane so that cells undergo lysis ${ }^{24}$. The mechanism of the action of saponins as antibacterial is by causing leakage of proteins and enzymes in the cell. Tannins also have a function to denaturate bacterial cell proteins that inhibit bacterial growth $^{25}$.

\section{CONCLUSION}

Dragon fruit leaves extract has antibacterail activity against meningitis bacterial (Neisseria meningitidis, Streptococcus pneumoniae, and Listeria monocytogenes). Red dragon fruit leaves extract was more potential antibacterial activity than white dragon fruit leaves extracted against meningitis bacterial (Neisseria meningitidis, Streptococcus pneumoniae, and Listeria monocytogenes)

\section{ACKNOWLEDGEMENT}

The authors acknowledge the laboratory support by PT. Mutiara Mukti Farma Pharmaceutical Industry, Sidodadi, Deli Tua, Deli Serdang, Sumatera Utara, 20355, Indonesia.

\section{REFERENCES}

1. Jayaraman, Y.; Veeraraghavan, B., Purushothaman, G.K.C.; Sukumar, B., Kangusamy, B.; Kapoor, A.N.; Gupta, N.; and Mehendale, S.M. Plos One., 2018, 13(5), 1-13.

2. Nerdy, N.; and Manurung, K. Rasayan J. Chem., 2018, 11(3), 1183-1194.

3. Nerdy, N. Int. J. ChemTech Res., 2015, 7(1), 148-152.

4. Nerdy, N. Asian J. Pharm. Clin. Res., 2017, 10(10), 183-186.

5. Nerdy, N. Int. J. PharmTech Res., 2015, 7(1), 47-53.

6. Nerdy, N.; Putra, E.D.L.; Haro, G.; and Harahap, U. Int. J. PharmTech Res., 2016, 9(6), 388-394.

7. Nerdy, N.; Putra, E.D.L.; Haro, G.; Harahap, U.; Hutagaol, R.; and Karsono, K. Int. J. Pharm. Pharm. Sci., 2015, 7(2), 485-488.

8. Ginting, N.; Suwarso, E.; Rumapea, D.V.; and Nerdy, N. Asian J. Pharm. Clin. Res., 2018, 11(1), 1-4.

9. Haro, G.; Sinaga, S.M.; Iksen, I.; Nerdy, N.; Theerachetmongkol, S. J. App. Pharm. Sci.,
2017, 7(8), 222-225.

10. De Freitas, S.T.; and Mitcham, E. J.; Sci. Agric., 2013, 70(4), 257-262.

11. Soeparjono, S. Int. J. Adv. Agric. Environ. Engg., 2015, 2(2), 79-82.

12. Choo, W.S.; and Yong, W.K.; Pelagia Res. Lib. Adv. App. Sci. Res., 2011, 2(3), 418-425.

13. Dasaesamoh, R.; Youravong, W.; and Wichienchot, S. Int. Food Res. J., 2016, 23(6), 2581-2587.

14. Omidizadeh, A.; Yusof, R.M.; Roohinejad, S.; Ismail, A.; Bakar, M.Z.A.; and Bekhitb, A. E. D. A. Royal Society of Chemistry (RSC) Advances., 2014, 4, 62978-62986.

15. Sudha, K.; Baskatan, D.; Ramasamy, D.; and Siddharth, M. Int. J. Agric. Sci. Res., 2017, 7(5), 451-456.

16. Nurliyana, R.; Syed Zahir, I.; Mustapha Suleiman, K.; Aisyah, M.R.; and Kamarul Rahim, K. Int. Food Res. J., 2010, 17, 367-375.

17. Shafie, S.R.; Yusuf, R.M.; Rahmat, A.; and Al-Saufreen, A.M. Int. Conf. Nutr. Food Sci., 2012, 39, 215-221. 
18. Islam, A.M.T.; Chowdhury, M.A.U.; Uddin, M.E.; Rahman, M.M.; Habib, M.R.; Uddin, M.G.M.; and Rahman, M.A. Eur. J. Med. Plants., 2013, 3(4), 500-507.

19. Nazliniwaty, N.; Karsono, K.; Zebua, N.F.; and Nerdy, N. Der Pharma Chem., 2016, 8(20), 207-213.

20. Nazliniwaty, N.; Karsono, K.;Zebua, N.F.; and Nerdy, N. Der Pharmacia Lettre., 2016, 8(20), 84-94.

21. Karsono, K.; Patilaya, P.; Azisah, N.; and Nerdy, N. Int. J. PharmTech Res., 2015, 8(4),
696-701.

22. Masfria, M.; Haro, G.; Nerdy, N.; Mierza, V.; Wahyuni, H.S.; Permata, Y.M. Int. J. PharmTech Res., 2016, 9(11), 110-120.

23. Kawakami, N.; and Fujisaki, S. Biosci. Biotech. Bioch., 2017, 82(6), 940-946.

24. Zhang, L.;Lilley, C.J.;Imren, M.; Knox, P.; and Urwin, P.E. Front. .Plant Sci., 2017, 8(1087), 1-12.

25. Nirwana, I.; Rianti, D.; Soekartono, R.H.; Listyorini, R.D.; and Basuki, D.P. Vet. World., 2018, 11(3), 342-347. 